Research, part of a Special Feature on Local, Social, and Environmental Impacts of Biofuels

\title{
Jatropha in Mexico: Environmental and Social Impacts of an Incipient Biofuel Program
}

\author{
$\underline{\text { Margaret Skutsch }}^{1}, \underline{\text { Emilio de los Rios }}^{2}, \underline{\text { Silvia Solis }}^{3}, \underline{\text { Enrique Riegelhaupt }}^{2}, \underline{\text { Daniel Hinojosa }}^{1}, \underline{\text { Sonya Gerfert }}^{4}, \underline{\text { Yan Gao }}^{3}$, and $^{\text {Ond }}$ \\ Omar Masera $^{3}$
}

\begin{abstract}
Three case studies from Mexico are presented in which the impacts of the recent introduction of jatropha cultivation for biodiesel production are examined. In Chiapas and Michoacan, local social and environmental impacts were assessed using interviews with key informants and questionnaires directed at three groups of stakeholders: jatropha cultivators, farmers in the same areas who are not cultivating jatropha, and laborers on jatropha farms. Results show that the farmers are primarily motivated to participate by the subsidies offered in a government program in the first 2 years, rather than any proven economic benefit. Our farm budget study indicated that profits would be marginal for these farmers. However, no cases of land alienation were involved, and impacts on food security and deforestation are currently not significant. Employment opportunities for landless laborers have increased in areas where jatropha is now grown. The program is only in its third year currently, so these outcomes would need to be reexamined as it develops. In Yucatan, production is mainly in the hands of commercial companies, using estates formerly under low-intensity grazing and secondary forest. A carbon balance analysis indicated that there may be a significant loss of carbon stocks associated with jatropha plantation establishment on these estates. Depending on the maturity of the forest regrowth and the intensity of jatropha production, the carbon payback period varies from 2 to 14 years, although, in some scenarios, the carbon debt may never be recovered.
\end{abstract}

Key Words: biodiesel; carbon balance; estates; smallholders; sustainability

\section{INTRODUCTION}

Production of biofuels is a contested issue in that it could result in negative environmental and social impacts locally (e.g., deforestation and resulting loss of local forest products and services, displacement of food production, and alienation of farmers from their land) as well as positive ones (income generation, employment creation, and diversification of livelihood strategies). For example, Ariza-Montobbio and Lele (2010), in the case of Tamil Nadu in India, find that jatropha cultivation on private lands not only fails to alleviate poverty, but risks creating conflicts between farmers and government and between different social classes; moreover, it may potentially compete with other crops for scarce water resources. On the other hand, the work of Sulle and Nelson (2009) in Tanzania indicates that outgrower production of jatropha has not had negative impacts on land access and that this model offers positive models for local livelihoods. McCarthy (2010), researching the case of oil palm (also used for biodiesel), argues that outcomes are highly dependent on local conditions and on the terms under which small farmers are engaged in program promoting such crops. This indicates the need for more detailed and local-level studies to investigate local circumstances and how they affect outcomes of jatropha production. Another very important consideration is impact on environment, in particular the extent to which biofuels will help to mitigate global climate change, if the cultivation of the feedstock entails clearance of forests and high levels of inputs. Although there have been some studies on this topic (Reinhardt et al. 2007, Becker 2009), this again may be dependent on local conditions.

The study described investigates the extent to which positive and negative impacts, both social and environmental, occur, even early in the implementation of a biofuel program, and attempts to document and explain them in the context of the particulars of one biofuel initiative. It focuses on jatropha grown for biodiesel in Mexico under a program that began in 2007, with first plantations in 2008. Jatropha was selected as the biofuel of focus in the research because it has been described in the literature as a crop that grows on wasteland (Robinson and Beckerlegge 2008), with the implication that it therefore does not impact food production or forest cover. Moreover, it has, in some texts, been specifically held up as a "poor man's crop" (Openshaw 2000) with the potential to bring economic benefits to marginalized and small farmers, although more recent research, as noted already, has nuanced this claim. The intent is to examine the early results of the Mexican jatropha program in order to contribute further evidence on both the social and the environmental issues to the body of literature on this topic. It first investigates the local environmental and social impacts of the Mexican jatropha program in two states, Chiapas and Michoacan, where jatropha was introduced as a smallholder crop in 2008 and is mainly replacing maize; then, it looks at the global environmental impacts by making a carbon balance analysis for the case of one jatropha estate in Yucatan, where it is replacing secondary

\footnotetext{
${ }^{1}$ Centro de Investigaciones en Geografia Ambiental, Universidad Nacional Autonoma de Mexico, ${ }^{2}$ REMBIO, Mexico, ${ }^{3}$ Centro de Investigaciones en Ecosistemas, Universidad Nacional Autonoma de Mexico, ${ }^{4}$ University of Twente, the Netherlands
} 
forest (acahual) formerly used for grazing. The analysis of local environmental and social impacts is based largely on the views of farmers and other rural people in the jatrophagrowing areas. Fieldwork was carried out in 2009 and 2010 with the aim of understanding, explaining, and illustrating the socioeconomic and environmental processes that operate at the local level. The carbon balance analysis was carried out in situ and involved physical measurements of jatropha bushes at different ages and secondary data on carbon stocks in the acahual.

The remainder of this introduction follows the debate around jatropha as a biofuel crop and describes the Mexican jatropha program. The methodology is then presented, followed by results and conclusions.

\section{Opportunities and risks of jatropha cultivation}

Jatropha has been portrayed as a "poor man's biofuel" crop, because it is a plant that can grow on wasteland in relatively dry climates (Openshaw 2000). It has been introduced successfully for small-scale production of combustible fuel for local consumption. In Mali, where it has traditionally been used for live fences and its oil extracted for soap making, the NGO Mali Folkcenter promoted community-level jatropha cultivation and oil extraction for use in so-called "multifunctional platforms" in the mid-1990s. These platforms consist of a generator for electricity and various kinds of processing machinery (grain mills, saws, as well as the oil extractor), and are operated by women's groups. In Koulikoro, also in Mali, a farmers' union is the major shareholder in a commercial enterprise producing biodiesel fuel for local use (Lengkeek 2007). Very positive reviews about the "miracle" plant appeared in the literature (e.g., Openshaw 2000, Robinson and Beckerlegge 2008), and the donor community became enthusiastic about the potential of jatropha to support local livelihoods.

Many small-scale jatropha projects have been proposed with the aim of providing energy access to the poor, while at the same time creating sources and means for income generation, promoting rural development, and mitigating environmental pollution (UN ESA 2007). For example, UNDP took up the Mali platform idea and expanded it greatly in a number of countries in West Africa. Ghana, Mozambique, Zambia, and Tanzania have all established some small-scale jatropha cultivation, and outcomes are said by some to have been positive, resulting in economic and social development, especially for women (UN ESA 2007), although recent research throws doubt on this (German et al. 2011). In Zimbabwe, a number of organizations are providing technical assistance to the manufacturing of products using jatropha (Ham 2004). Underlying many of these initiatives is the idea that poverty and lack of energy are linked, and that availability of local energy is fundamental to agricultural development and thus to poverty alleviation (Raswant et al. 2008).
Jatropha is drought tolerant, appears to have low nutritional requirements, and is relatively resistant to pest and disease, particularly when grown in mixed agriculture or as a boundary plant, and it yields useful combustible oil. This has raised high, and possibly unrealistic, expectations regarding simultaneous wasteland reclamation, fuel production, poverty alleviation, and large returns on investments (Jongschaap et al. 2007, Achten et al. 2010a). The fact that it commonly grows on wasteland and as a live fence has led many people to believe that it will pose no threat to forests or food crops. However, on the basis of the limited evidence available, there are indications that when jatropha is grown on a large scale, it may result in considerable deforestation. In Paraguay, for example, the forests of Totobiegos were destroyed and clear cut with machinery to create fields for the production of jatropha, promoted by private energy companies from Argentina (WRM 2009). In Ghana, destruction of vegetation cover as a result of the establishment of large jatropha plantations has been observed (WRM 2008, Schoneveld et al. 2011).

Most of the claims relating to the benign and tolerant characteristics of jatropha have, in fact, not been proven in scientific literature, and there are issues, such as water requirements and water footprint, that need to be considered if jatropha is to be used as a biofuel feedstock on a large scale (Gerbens-Leens et al. 2009). High levels of inputs, including irrigation and fertilizer, raise yields considerably, and pesticides are usually required when jatropha is grown under monocultivation. Furthermore, when biodiesel is being produced not for local use but for commercial markets, either national or international, as is the case in Mexico, a different mode of production may prevail and questions may begin to arise concerning its social benefits.

The change in scale of production that is implied in supplying external markets may result in displaced food production and encourage land consolidation by larger farmers and companies. Empirical studies in India have claimed that jatropha production is neither profitable nor pro-poor, but favors resource-rich farmers while possibly further marginalizing smaller farmers (Ariza-Montobbio et al. 2010). For example, in Kanker and Bastar districts of Chhattisgarh, 210 families in 18 villages were displaced from 1059 ha of land forcibly acquired for jatropha cultivation (Lahiri 2009). An additional 355 tribal families in 27 other villages were displaced for the cultivation of jatropha on their land. According to a local nongovernment organization, more than 710 ha of land cultivated by these adivasis (tribals) for generations were taken away from them for planting jatropha (WRM 2009).

There are additional questions about the oil yields that can be expected in different ecozones and under different management regimes. More information is gradually becoming available on both plant growth characteristics and 
water requirements (Kheira and Atta 2009, Achten et al. 2010b, Pruekaskorn et al. 2010). What is clear is that the provenance of the seeds is very important (Achten et al. 2010a). There are many genotypes that have different basic production potential regarding jatropha fruits. Furthermore, depending on growth conditions, the number of seeds per fruit can vary from one to three, and the oil yield from seeds may vary from $25 \%$ to $50 \%$ by weight (Achten et al. 2010b). There are many insect pests that attack different parts of the plant, including seed borers, about which little is known; hence, pesticides will be a necessary part of the management in many places. Termites may be a problem in Africa, although these could possibly be managed without resorting to pesticide use (Wardell 1987).

The remains of the jatropha seed after oil extraction are in the form of cake, and there are possibilities that this could be used as fertilizer or as cattle feed (Openshaw 2000, Achten et al. 2010a, Prueksakorn et al. 2010). Most genotypes contain toxic phorbol esters, but there are at least two genotypes originating in Mexico that are free from this (Achten et al., 2010a). The phorbol esters are said to decompose within 6 days if the cake is spread as mulch, but the effects as a fertilizer have not been widely tested. The costs of inputs, the organization of production and processing, and the possible uses of secondary products like jatropha cake could be very important in the viability of jatropha as a crop in general and particularly as an income-earning opportunity for local people. However, there have been very few studies on the impact of jatropha cultivation at the local level and certainly none that have taken into account all these factors. Similarly, the necessary labor inputs have not been documented. Meanwhile, jatropha has become an estate crop as well as a smallholder crop as commercial interest in the prospect of biofuels has increased. With more capital and management capacity, these estates may be more profitable than smallholder units and could provide employment opportunities for the local population. However, as with all such production systems, there are risks regarding land alienation and job security, as well as displacement of local livelihoods (Tandon 2009).

\section{Characteristics of the jatropha program in Mexico}

The broad context of the study is the Mexican government's commitment to developing new initiatives to create and promote alternative sources of energy, to diversify fuel sources, and to create less-polluting energy mixes by reducing dependence on fossil fuel. In 2008, the Law for the Promotion and Development of Bioenergy (LAERFTE 2008) was promulgated with a view to reducing dependence on fossil fuels and achieving more sustainable development. The aim is to produce biofuels and bioenergy efficiently for the market, at the same time providing stimulus to the agricultural sector. The policy was further defined in the Bioenergy Interministerial Strategy (2009-2012), which describes the Bioenergy Introduction Programme. This aims for sustainable bioenergy feedstock production and scientific and technological development. It envisages bioethanol production primarily from sugar cane, sugar beet, and sweet sorghum and biodiesel mainly from jatropha, oil palm, and castor. Although targets have been set for bioethanol use, particularly for use in the larger metropolitan areas, there are no quantified targets yet for biodiesel. However, the government is offering support to jatropha production, through the ProArbol program of CONAFOR, the National Forestry Commission.

CONAFOR operates a comprehensive program, known as ProArbol, that provides financial and technical assistance to landowners of all types to protect, conserve, restore, and sustainably manage the country's forest resources. Since 2007, one of the elements within this has been a subprogram that provides subsidies for the promotion of jatropha, a native shrub suitable for cultivation on previously cleared forest lands that are now considered wastelands; its plantation is seen as a form of reforestation. Jatropha has traditionally been grown as a hedge, and its oil seeds are often used for medicinal purposes and for soap making, and two of the nontoxic varieties are also sometimes used as a source of food. Under ProArbol, however, the emphasis is on the production of oil for biodiesel. CONAFOR publishes information regarding the conditions of eligibility for farmers participating in the program and the rates at which subsidies are paid. Subsidies are extended on the basis of a predetermined set of norms, which include preselected administrative areas where the program applies. There is a complex evaluation system in which points are given against a large number of criteria.

In 2008, poor and marginalized communities were supposed to get higher priority than more commercialized settlements. However, by 2010, this had changed such that more points are allocated to rural commercial associations and societies, and points are also given to groups that are working with a 10-year investment plan and those that are already associated with an industrial market for the jatropha crop. In other words, there appears to be a shift underway from the focus of jatropha as a crop for small farmers toward support for more organized and industrialized production. The reasons for this are not clear, but it may have to do with the need to increase areas planted.

The program is open to farmers in ejidos (communal agrarian settlements) and other communities. To participate, the farmer has to provide documentation relating to his rights to the land concerned. The subsidy was 6310 pesos (US\$488) per hectare for farmers starting in 2008 and 7394 pesos (US\$572) per hectare for farmers starting in 2009. The same rates apply to commercial jatropha estates. The operation of the program has not been unchallenged; in 2009, a group of small landholders publicly denounced CONAFOR, arguing that producers from more than 14 districts were being denied subsidies and that 
help was instead being given for reasons of political favoritism to producers in other districts that lack both the technical and the geographical requirements for growing jatropha (Universal 2009). Collective action by jatropha cultivators has also been observed in Zambia (German et al. 2011).

Information on how many farmers have taken up the subsidies and the acreage of their jatropha plantations has been published online for 2010 and 2011 but not for the first 2 years of the program. At the time fieldwork was carried out, no data were available at the local CONAFOR offices. There appeared to be confusion between statistics on areas that had been declared generally suitable for jatropha, areas of individual farm land that had been approved for subsidies, areas that had received subsidies, and areas that had actually been planted. There were also scattered reports concerning private companies starting jatropha plantations using CONAFOR subsidies in various parts of the country, for example, 2000 ha in Yucatan (IICA 2009), 400 ha in Tamaulipas (Milenio 2010a), and 94 ha in Tabasco (Milenio 2010b).

The jatropha program being promoted by CONAFOR is a national program but has followed very different paths in different states, in part as a result of different socio-agronomic conditions. In Yucatan, the target area is in the north of the state, where land is under two forms of ownership: ejidos (communal agrarian settlements) and private ranches, now mostly used for low-intensity cattle rearing. Agriculture in the north Yucatan ejidos is mainly based on a traditional long rotation swidden system (milpa) for maize, beans, and squash, which is well suited to the very thin soils, provided the cycles remain long (ideally 25 years). There is much secondary forest (acahual) in the landscape, which gives the impression that a large part of the land is not in production, but in reality, it represents the fallow stage in the production cycle. Cultivation of jatropha, which is a perennial crop, would require removing land from this cyclical system. According to officials at the local CONAFOR office, farmers have shown very little interest in participating in the program, and this was confirmed in an interview with one small farmer who has a small jatropha plantation near Tizimin. Apparently, only 20 of the farmers contacted by the program initially showed any interest, of which seven planted some jatropha. Of these, only two have maintained their plantations. Low germination rates and unfamiliarity with the crop, combined with uncertainty about payment schedules, may have been responsible for this. The result has been that, in this state, CONAFOR has worked mostly with commercial ranches, providing subsidies for some of them. Cattle rearing is not a high-profit option in this area, and jatropha has been seen as a potential alternative use of the land, with the aim of exporting biodiesel to the United States or Europe via the northern Yucatan ports.

In contrast, in Chiapas and Michoacan, there are no companybased plantations. CONAFOR has successfully targeted smallholders in ejidos in areas that it has nominated as suitable for jatropha cultivation. A minority of these farmers practice shifting cultivation; most have permanent fields. As in Yucatan, the program works on the basis of a subsidy, which is intended to offset start-up costs. First, technical advice is given to the farmers, and 3 months after planting, an inspection is made to ensure that the planting density is according to the standards set, that there is at least a $70 \%$ survival rate, and that at least $80 \%$ of the remaining plants are in good health. If these conditions are met, a payment representing half of the full subsidy is made. The second payment is made a year later after a similar inspection. By the end of the second year, it is expected that the farmers would be able to earn some money from sale of seeds, the production of which should increase every year for the first 5 years.

The program in Chiapas has had considerable support from state politicians with a view to a local market for biodiesel, supplying the public transport sector. Several small processing plants have been built, including one set up in collaboration with Colombia, although this is not operational yet. In Michoacan, though feedstock production is in the hands of smallholders in ejidos, a number of foreign companies have invested in biodiesel refining capacity and have become intermediaries between CONFOR and farmers. These intermediaries manage the subsidies provided by CONAFOR and provide technical assistance as well as buying the harvested jatropha seeds.

\section{METHODOLOGY}

The three states selected for this study-Yucatan, Chiapas, and Michoacan-were among the first to start growing jatropha in the program (Fig. 1). As noted, definitive figures are not available for the early years, but according to local key informants, by the end of 2010, there were about 2500 ha planted in Yucatan, 2000 ha in Chiapas, and between 1000 and 2000 ha in Michoacan, although much larger areas had been approved for planting (CONAFOR 2010). It is important to understand that few farmers in these areas have yet had any significant yields, as the jatropha bushes need at least 2 years to bear fruit. In each of the three states, interviews were first carried out with relevant government agencies and with organizations such as associations of jatropha cultivators to identify settlements where the program was operating. This allowed us to select clusters of settlements (5-6 villages) in Chiapas and in Michoacan, where socioeconomic surveys were carried out using household interviews. A farm budget analysis was made on the basis of information gathered in these two states, and a carbon balance study was made on the basis of data from a commercial farm in Yucatan, where, as explained above, feedstock production is largely in the hands of large companies, not smallholders. 
Fig. 1. Location of Yucatan, Chiapas, and Michoacan states.

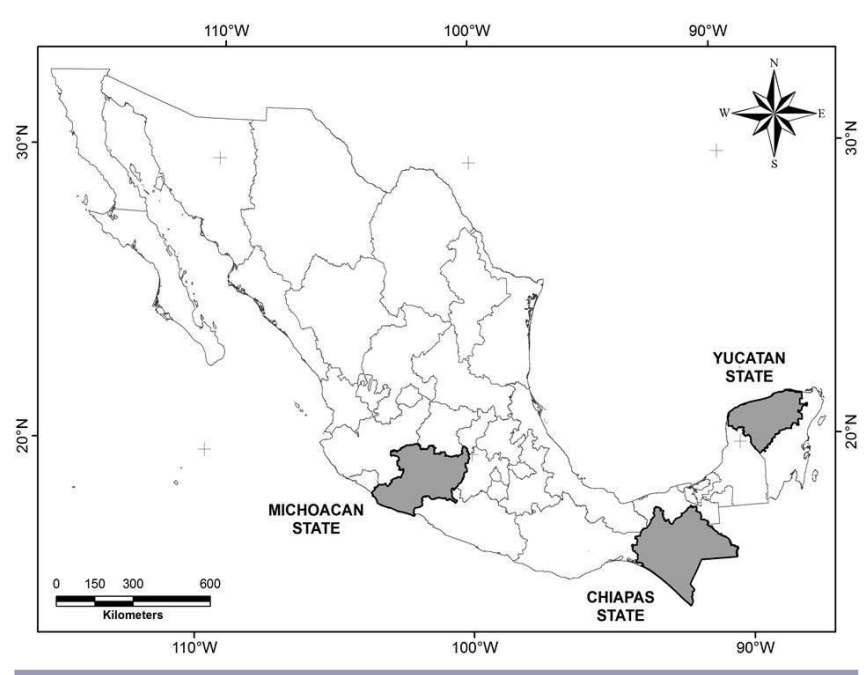

\section{Socioeconomic surveys}

In the two states in which significant numbers of smallholders are engaged in jatropha production (Chiapas and Michoacan), villages were selected on the basis of when they joined the program and the numbers of farmers involved. (We selected villages with the most early starters.) A set of questionnaires was developed for different social groups: smallholders cultivating jatropha, smallholders (in the same village) not cultivating jatropha, and laborers on farms where jatropha is being grown and in nurseries. Although government offices officially have lists of cultivators in each village, in practice this information could not be obtained. Within the villages, the sample of cultivators was chosen after discussion with key informants, who were able to identify larger and smaller jatropha farmers. Noncultivators and laborers were chosen by identifying residential areas that were richer and poorer on the basis of house materials, and then selecting every tenth house along a typical street. The wealth index used to classify respondents in the interview combined observations relating to the quality of house and ownership of material possessions (TV, radio, vehicle). In Chiapas, 34 households were interviewed (21 cultivators, 10 noncultivators, and 3 laborers), and in Michoacan 38 ( 23 cultivators, 11 noncultivators, and 4 laborers).

\section{Farm budget study}

On the basis of information on current crop prices and inputs into jatropha production gathered during the household surveys in Chiapas and Michoacan, we conducted a farm budget study to estimate the level of profitability of jatropha to cultivators. Most farmers had cultivated for only 1 or 2 years, so very little had yet been harvested and their information on costs and returns was not complete. Expert opinion was therefore used for a number of variables, such as the rate at which a laborer can harvest jatropha fruits and extract the seeds. For the analysis, two possible shadow prices were used for (fossil fuel) diesel: the local Mexican price before tax and the international price. This enabled us to calculate a breakeven price for jatropha seed at the farm gate.

\section{Carbon balance study}

An analysis was made of the carbon balance at a commercial farm in Yucatan where secondary forest had been cleared for the jatropha plantation. This analysis consisted of (1) estimates from secondary data of the loss of carbon from secondary forest (acahual) cut to make way for jatropha production (Eaton and Lawrence 2009; Torres Perez and Vargas Perez, personal observations); (2) estimates of the carbon that is sequestered in the jatropha plants as they mature, since they are perennials with a probable working life of 20 years; and (3) very rough estimates of the carbon savings that result from substitution of biodiesel for fossil fuels in the end use. The sequestration of carbon in the jatropha plants was estimated based on measurement of plant dimensions in two parts of the jatropha plantation, one with a high rate of growth (sample of 30 plants), the other with a more typical rate of growth (sample of 40 plants). Samples were weighed wet and oven-dry to estimate the mass. Allometric equations were developed to estimate the carbon content of jatropha plantations of different ages. Although it was not possible to carry out a complete cradle-to-grave analysis, a broad estimate was made of the probable overall gains and losses of carbon.

\section{RESULTS}

\section{Impacts of jatropha on deforestation}

The jatropha program has only been in operation for 3 years, and therefore its impacts on forests are a priori likely to be limited at this point in time. Spatial quantification of forest loss (e.g., using remote sensing) has not been attempted in this study, not least because time series images at a resolution sufficient to pick up the small areas cultivated, to distinguish jatropha from other crops, and to distinguish areas of different forest densities are not available for the period over which jatropha has been introduced. It should be noted, however, that officially plantation of jatropha results in afforestation or reforestation, since it is considered a "tree" by the CONAFOR and the program falls under a national program concerned with increasing forest area. At the time this research was carried out, two commercial ranches in Yucatan had planted about 350 ha and 2000 ha of jatropha, respectively; both are in the process of expanding their plantation areas considerably. One of the farms had not been used for cattle rearing for some time and combined jatropha with pig breeding, using as manure slurry from the biogas plants that had been constructed earlier. The terrain of both estates is gazetted as "grazing land" rather than forest, because of its former use; but, in both cases, the estate area is in fact covered with secondary forest (acahual) 
of different ages, which has grown because grazing intensity had been too low to stop natural regeneration. Some clearance of trees was therefore necessary to plant jatropha. Clearance was done by tractor and chain, and the wood was chipped rather than burned; some has been used as mulch. Assessing the quantity of biomass lost as a result of the clearance is difficult, not only because records have not been kept, but also because there is continual expansion of the planted area. Also, the density of the biomass (and thus the carbon stock per hectare) depends on the age of the acahual. This is not uniform but varies greatly over the area. Nevertheless, it is clear that there is a continuing loss of living woody matter, even if part of the residue is returned to the soil and the forest is replaced by jatropha, a perennial shrub.

In Chiapas, the majority of jatropha farmers interviewed (14/21, all smallholders) have converted maize (often grown together with peanuts) or other food crop fields for establishment of jatropha, whereas six farmers used pasture land. Only one farmer (5\% of respondents) cleared a forest plot for his jatropha fields. In most cases, the land selected by the farmers was land that had experienced falling yields of maize over the last few years, although in three cases, prime irrigated land was used. It is clear that there is very little direct deforestation connected with the cultivation of jatropha, although if maize is displaced, indirect deforestation may be occurring elsewhere. It is impossible to say where this displacement would occur; it need not even be within the national boundaries.

In Michoacan, the story presented by the bioenergy companies, who as noted above are purchasing the seeds and acting as intermediaries, is that low-value agricultural land is being used by smallholders for "reforestation" with jatropha, and this was observed to be the case in some areas. Much of the area used for jatropha is land that is normally part of a shifting cultivation system. Of jatropha cultivators practicing shifting cultivation, who represent more than $50 \%$ of the total, about half cleared a patch of secondary forest to plant the jatropha, whereas the rest used fields that had been under maize the previous year. However, jatropha was also observed on land used permanently for agriculture, and in a few areas, even on prime, irrigated land, which is in no sense "marginal". In one of the five villages surveyed in Michoacan, all the cultivators interviewed (5) were using irrigation. In Michoacan, there was more evidence than in Chiapas that woody vegetation is being cleared and taken out of a rotation system of agriculture for jatropha cultivation. At present, however, the total area devoted to jatropha in both states is minimal, and the losses are therefore very small. Should jatropha become highly profitable, however, the loss of secondary forest, the displacement of food production, and possible indirect deforestation effects could be major issues.

\section{Social impacts}

One of the major concerns with biofuel production is that it may have negative social impacts as well as positive ones. Findings are organized around major types of possible impacts, including the following: (1) dispossession of smallholders from their land by large-scale commercial companies, with the result that farmers become landless laborers or have to leave the area completely; (2) entrapment of smallholders in unfavorable purchasing and contract conditions, resulting in loss of freedom to pursue more profitable activities; (3) increased socioeconomic disparities in communities and concentration of biofuel-related wealth in the hands of a few, with possible associated increase in social conflicts and loss of community cohesion; (4) increased workloads on women due to additional field labor and processing activities; (5) reduced food supply and increases in food prices if land is converted from food to fuel production; and (6) loss of forest services and products if forests are cleared for production. On the positive side, impacts could be increased income from employment or jatropha cultivation, and increased diversity in sources of income, as well as improved community infrastructure.

\section{Dispossession of smallholders by companies}

In the case studies carried out for this research, there was no evidence that smallholders were losing land to commercial companies, although this has been observed in parts of Africa and Asia (WRM 2008). In one village in Michoacan, a few high-value agricultural plots were observed to have been leased by (richer) farmers to employees of the energy company, but this cannot be said to represent involuntary dispossession. In Yucatan, the program has up to now concentrated on privately owned estates, some of which are receiving subsidies from the CONAFOR. In Chiapas, there is some evidence that smallholders with more land are more likely to join the program than those with smaller holdings (see below), but no cases of land transfer were identified.

\section{Entrapment of smallholders}

In the sites surveyed, there was little evidence of long-term entrapment as a result of contractual agreements. In Michoacan, where administration of the (state-financed) subsidy payments to the farmers had been taken over by the bioenergy firms, it appeared that farmers had to sign that they would sell their harvest only to the company, and not on the open market. The company had not yet purchased any of the product, although in some villages, some farmers had harvested a small quantity. This has left the farmers uncertain, particularly as there is no counter clause obliging the companies to purchase and no guaranteed purchase price. In one village, four farmers had pulled up their 2-year-old plants because they did not trust the company anymore. Elsewhere, a few farmers had pulled up their plants because the second subsidy payment had not been made, as will be explained 
below. We noted also that the selling price for the jatropha seeds was not clear to the farmers in either Chiapas or Michoacan and was not specified in contracts or in any other documents available to them.

Although farmers were not officially told what the farm gate price of the seeds would be, 7 pesos per kilogram (US\$0.50) was the figure that had apparently been suggested by program technicians in Chiapas, and 4 pesos (about US\$0.35) in Michoacan (source: field interviews with farmers). Our farm budget survey (Appendix 1) shows that, based on current fossil diesel prices, 1.6-2.3 pesos per kilogram would likely be the maximum that could be paid, and that at this rate there would be very little profit for the farmers. It was evident, however, that the farmers had joined the program not on the basis of the likely profit they would make on selling the seeds, but simply because the subsidies provided were such that they would more or less break even compared with maize production in the two initial years. Farmers appear to have regarded jatropha as a reasonable experiment and will wait to see what the price really is before deciding whether to continue with jatropha or to pull it up and grow grains again, indicating that entrapment is not an issue here. As one farmer noted, "We are contracted to sell the seeds to company X. If they don't come and buy them or the price is too low, we will pull the plants up and grow maize. At least we can eat that, even if we can't sell it."

It also appeared that farmers did not always fully understand the terms of the agreement, or were not able to meet conditions such as planting density and plant health, and this resulted in conflict and resentment when, on these grounds, the second subsidy installment had not been paid. Payments were, in any case, delayed in many cases, causing frustration and fomenting lack of trust in the system. (In Michoacan, one bioenergy company acting as intermediary had pulled out, another apparently had cash flow problems. In Chiapas, where CONAFOR was managing the subsidies via extension workers, the reasons are not so clear.)

Common complaints about contractual matters concern the fact that not all farmers who wished to participate were permitted to do so; this could have socially divisive implications and is discussed below.

\section{Increased social disparities}

In Chiapas, it is evident that the majority of jatropha cultivators in the ejidos have holdings that are larger than average; commonly, 5 ha is planted with jatropha out of 20 ha of total landholdings, but there are variations, and there are also some smaller landholders with 1 ha of jatropha in a 5-ha landholding (Table 1).
Table 1. Socioeconomic differences between jatropha cultivators and noncultivators in Chiapas.

\begin{tabular}{|c|c|c|}
\hline Parameter & $\begin{array}{c}\text { Jatropha } \\
\text { cultivators } \\
(n=21) \\
\end{array}$ & $\begin{array}{c}\text { Noncultiv- } \\
\text { ators } \\
(n=9) \\
\end{array}$ \\
\hline Average landholdings (ha) & 19 & $<10$ \\
\hline Average area under jatropha (ha) & 4.75 & - \\
\hline -Largest jatropha holding & -16 (of $20 \mathrm{ha})$ & \\
\hline -Smallest jatropha holdings & $\begin{array}{c}-1 \text { (of } 6 \text { ha); } 1 \\
\text { (of } 25 \text { ha) }\end{array}$ & \\
\hline $\begin{array}{l}\text { Average no. adults in family (> } 16 \\
\text { years) }\end{array}$ & 4 & 4.3 \\
\hline $\begin{array}{l}\text { Average no. dependents }(<16 \\
\text { years) }\end{array}$ & 1.5 & 1.0 \\
\hline $\begin{array}{l}\text { Years of education of head of } \\
\text { household }\end{array}$ & $6-9$ & $0-6$ \\
\hline Wealth index ${ }^{\dagger}$ & $85 \%$ & $50 \%$ \\
\hline
\end{tabular}

$\doteqdot \%$ of sample group rated rich or average on basis of material possessions [vehicles, TV] and type of house owned by the household

Noncultivators in the sample in Chiapas were on average poorer than cultivators (Table 1), which, given the fact that there have been almost no yields yet, would appear to be a cause rather than a consequence of nonparticipation. The reasons they themselves gave for nonparticipation were the following: insufficient land ( 2 respondents); no security from grazing animals on their land (1 respondent); and lack of labor due to sickness, age, or other employment (5 respondents). Two indicated that they might be interested in the future; the remaining six were clear that they would not participate even in the long run. Noncultivators had generally lower levels of education, but their family size was not significantly different from that of cultivators.

Only a few laborers were interviewed (4); all were from landless families, that is, they were offspring of ejido members who have no inheritance or families who had sold their ejidal land earlier to others. All were laborers normally working on food crop fields of larger farmers, who now work in addition on the jatropha fields of these better-off villagers. For the laboring families, the arrival of jatropha has provided a welcome additional source of income. Wage rates were said to be around 100 pesos per day (US\$7.7), which is almost double the national minimum day wage, and more work was available than before. In our survey, these interviewees rated their livelihood gains more highly than did any of the cultivators. They particularly appreciated the fact that the work 
is more constant than with food crops (e.g., weeding that has to be done regularly in the first years), which meant they had a steady source of income.

In Michoacan, the average total land holdings of cultivators were much larger than in Chiapas, and a few farmers owned considerable holdings outside the ejido in addition. The average area of jatropha cultivated by the 23 cultivators interviewed was 7.8 ha, but the largest two held 37 and 20 ha, respectively, whereas 7 held less than 5 ha. This demonstrates the fact that a wide range of farmers may be involved, but also that there are very large differences in underlying resource endowments and a wider dispersion of landholdings than we had observed in Chiapas. As noted earlier, some practiced shifting cultivation, and others had permanent fields. The average land holding of the shifting cultivators was 87 ha with on average 5.7 ha converted to jatropha. The average land holding of the permanent croppers was around 100 ha, of which they converted an average of 9.5 ha to jatropha. A total of $81 \%$ of the cultivators were assessed as average or rich on the basis of their apparent possessions. Noncultivators had considerably less overall land at their disposal, and a smaller proportion of them were ranked as average or rich (Table 2).

Table 2. Socioeconomic differences between jatropha cultivators and noncultivators in Michoacan.

\begin{tabular}{|c|c|c|}
\hline Parameter & $\begin{array}{l}\text { Jatropha } \\
\text { cultivators } \\
(n=23) \\
\end{array}$ & $\begin{array}{c}\text { Noncultiv- } \\
\text { ators } \\
(n=11) \\
\end{array}$ \\
\hline Average ejidal landholdings (ha) ${ }^{\dagger}$ & 94.7 & $\begin{array}{l}\text { Unreliable } \\
\text { data }\end{array}$ \\
\hline $\begin{array}{l}\text { Average area under jatropha } \\
\text {-Largest jatropha holding } \\
\text {-Smallest jatropha holding }\end{array}$ & $\begin{array}{c}7.8 \\
-37 \text { (of } 200 \text { in } \\
\text { ejido) } \\
-1 \text { (of } 94 \text { in } \\
\text { ejido) }\end{array}$ & $\mathrm{n} / \mathrm{a} \neq$ \\
\hline $\begin{array}{l}\text { Average no. of adults in family (> } \\
\text { 16) }\end{array}$ & 2.8 & 2.6 \\
\hline Average no. of dependents & 1.7 & 1.4 \\
\hline $\begin{array}{l}\text { Years of education of head of } \\
\text { household }\end{array}$ & $\begin{array}{l}\text { Secondary } \\
-3 \text { years }\end{array}$ & $\begin{array}{l}\text { Secondary } \\
-3 \text { years }\end{array}$ \\
\hline Wealth index & $81 \%$ & $55 \%$ \\
\hline
\end{tabular}

${ }^{\dagger}$ Three farmers also had private holdings outside the ejido of 2200, 150, and 249 ha, respectively, but these were not used for jatropha.

$\ddagger$ Insufficient numbers of the respondents gave data on this variable to estimate the average; however, lack of land was not indicated as a reason for not planting jatropha.

Nine of the eleven noncultivators interviewed had wanted to join the program and receive subsidies, but were rejected, on grounds that are not entirely clear in their statements in the survey; however, key informants in the village explained that this may have to do with lack of documentation relating to land tenure. CONAFOR records for reasons for refusal of subsidies in Michoacan in 2010 and 2011 show that a large proportion relate to lack of ownership papers. This could indicate a form of social exclusion induced by the formal requirements of the program. Only two declared that they were not interested in joining, stating that their land was too far or that they had livestock that would interfere with the plantation; none mentioned labor shortage or land shortage as a reason.

The laborers interviewed in Michaocan mostly worked in the nurseries and came from rather small families. The nurseries provide considerable numbers of paid jobs, particularly for women and children. However, this is only temporary in each location, as the production cycle is around 50 days, and the nurseries are removed as soon as the village has been supplied with the seedlings. Pay is low (and based on piece work), and most employees are secondary school children or women who bring along their small children. About half of the laborers thought the program had brought them more income, but others were doubtful, noting that nursery employment is temporary and tends to be reserved for women. The risk of serious exploitation of child labor is limited because the period of employment is very short. A number of the richer farmers complained that this employment opportunity had driven up the local wage rates, however.

In terms of the threat of increased social conflict and loss of social cohesion, we found no case in which jatropha cultivation had resulted in major social conflicts, partly relating to the fact that there were few cases of land transfers as a result of jatropha cultivation. In one settlement in Michoacan, three cases of leasing land were based on amicable agreements. The exclusion of farmers lacking land documentation could be considered a potential source of conflict, although negative social impacts were only expressed in relation to the selection of persons to work in the nurseries (in one village, it was alleged that employees were drawn from only one kinship group), and the fact that, in one village, water for cattle was being diverted to the nursery (apparently without any discussion at community level). Complaints about freeranging cattle damaging jatropha plantations were made in another village. No one indicated that there was any reduced accessibility to communal land. The noncultivators were unable to discern any negative impact of jatropha on their livelihoods or those of their fellow villagers.

\section{Increased workloads for women}

Regarding possible gender impacts, the responses to the questionnaires make it clear that jatropha is considered to be men's work, and for men's profit. The fieldwork was done by male family members, even in cases in which women owned the land. In almost all the holdings larger than 1 ha, male laborers were employed in addition to male family labor. The laborious work of decorticating the seeds has not yet been 
experienced on a large scale, however. This is generally done at the homestead, and in the few cases we observed, it was being done by women. It is hard work, requiring gloves, and in the future may be a very time-consuming task, the labor implications of which have not yet been explored.

\section{Loss of food supplies and food security}

Despite the fact that most of the jatropha is replacing maize, according to respondents it has not resulted in lower food availability among cultivators, who continue to produce sufficient amounts for their own family use. Most of the maize was surplus and sold, and even after planting some land with jatropha, most farmers are still selling maize. At the macro scale, of course, food supplies can be said to be reduced, but from the point of view of the cultivators, maize is seen as an unprofitable cash crop. Finding an alternative in these marginal areas, which are moreover at some distance from urban markets, has not been easy, and jatropha is clearly perceived by farmers as a possible candidate.

\section{Loss of forest services and products}

In the areas surveyed, it appears that jatropha has had almost no impact on the supply of forest services and products yet. In the case of Yucatan, the forests cleared for jatropha production had been under private ownership earlier; they had not been accessible to local villagers for firewood or nontimber forest products, and these products were not harvested by the owners. As the secondary forests are cleared, there may, however, be some loss of water catchment capacity and biodiversity. In Chiapas and Michoacan, the areas used were mainly already under cultivation or grazing, or woodland that forms part of an agricultural cycle, so there is some, but not a great deal of deforestation occurring. No one in these villages registered any loss of forest products and services (firewood, water supply, etc.) resulting from jatropha cultivation, and no negative impacts were mentioned regarding any of the other environmental indicators (crop pests, air pollution, soil erosion, etc.). This was a common view held by cultivators, noncultivators, and laborers alike. The sole item that was mentioned as an environmental problem at the community level was the disposal of the old plastic bags used in the nurseries in Michoacan, which were left lying around after the nurseries were dismantled.

\section{Gains in income, employment, and social infrastructure}

Because harvesting had just commenced at the time of our research, it is too early to give a definitive answer about the impacts of jatropha on household incomes. In response to questions about what profits farmers expect from the jatropha, farmers' expectations of yields ranged from 1.5 to 5 tons jatropha seeds per hectare per year. The figure of 5 tons seems to have been put about by the technicians working on the program and is at the high end of the range suggested by the Mexican government agricultural research organization
INIFAP; the Ministry of Agriculture suggests 2.5 tons per hectare as a starting yield, with a maximum potential of 5.0 tons. Such high yields may be possible on good sites from mature stock, under irrigation, and with high levels of inputs, but the average would likely be less than this (Reinhardt et al. 2008, Achten et al. 2010a), and it would of course take many years to build up to this level.

When asked to assess the likelihood of livelihood improvements as a result of jatropha, most cultivators did not appear to have very high expectations; only one respondent gave a strongly positive response to this question. In Michoacan in particular, there is evidently a growing feeling among farmers that 4 pesos per kilo will not cover the costs. The energy company operating as intermediary in many villages estimates that the real cost of establishing 1 ha of jatropha is around 10,000 pesos (source: interview with key informants), which is considerably more than the subsidy. Most families are using mainly family labor, the cost of which is usually underestimated, and separating the seeds from the fruit has not as yet been factored into their calculations, suggesting even lower returns to labor than are currently recognized.

Cultivation of jatropha implies loss of some income as a result of the curtailing of maize and peanut production. It was noticeable that the quoted selling price for these varied enormously from village to village, depending on the accessibility to market, but low maize price was stated as a motivation for changing to jatropha even in villages where higher farm gate prices prevail. As yields of maize are around 2 tons per ha and peanuts 0.75 tons per hectare, our estimate is that the typical return per hectare for mixed cropping is in the range of 1800-4000 pesos (US\$139-310), taking into account price differences due to accessibility. As shown in the farm budget survey (Appendix 1), at a price of 2.3 pesos per kilogram, yields would have to be 5 tons per hectare for the farmers to reach even the lower ranges of this, and in reality, yields are likely to be much lower than 5 tons.

A further consideration is that, at least in the first few years, labor inputs to jatropha are higher than to maize and traditional crops. This is because, after preparation of the soil, there has to be constant weeding to allow the jatropha bushes light and room to grow. All landless laborers surveyed noted the availability of more work opportunities as a positive development, as noted above. The highest cost in terms of labor input will be in harvesting, which is very time consuming as it requires several passes, as not all the fruits ripen at the same time. Farmers have not yet experienced this on any significant scale. There are relatively high costs associated with other inputs, such as fertilizer and pesticides, further undercutting profits.

It can be concluded that the farmers do not yet have a clear view of the input costs, the probable yields, or the selling price 
Table 3. Estimated biomass and carbon stock in acahual of different ages on the jatropha farm.

\begin{tabular}{lccc}
\hline \hline Age of acahual & $\begin{array}{c}\text { Approx. area } \\
\text { (ha) }\end{array}$ & $\begin{array}{c}\text { Above-ground biomass levels } \\
\text { (tons/ha) }\end{array}$ & $\begin{array}{c}\text { Above-ground carbon levels } \\
\text { (tons/ha) }\end{array}$ \\
\hline $1-5$ years & 1250 & $2.0-16.0$ & $\begin{array}{c}1.0-8.0 \\
\text { (average } 4.5) \\
5.0-11.0\end{array}$ \\
5-15 years & 4350 & $10.0-22.0$ & $\begin{array}{c}\text { (average } 8.0) \\
20.0-40.0 \\
\text { (average 30.0) }\end{array}$ \\
15-25 years & 3200 & $40.0-45.0$ & $60.0-80.0$
\end{tabular}

${ }^{\dagger}$ Note: This does not include below-ground biomass, which would be approximately 20\% more (Achard et al. 2004). We assume, however, that the below ground biomass would largely be preserved when the forest is cleared and gradually decompose in the soil, meaning that this carbon pool would not be lost in the short term (10 years).

Source: Eaton and Lawrence 2009; Torres Perez and Vargas Perez, personal observations.

of seeds. All the farmers we interviewed were, in fact, primarily motivated to plant jatropha by the presence of the subsidy, rather than by any clarity about the eventual payoffs. The thinking behind this seems to have been (1) maize does not bring in much income, and many were looking for an alternative; (2) the technicians employed by the program were very persuasive, assuring people that jatropha was a very good crop with a high yield and a high selling price; and (3) farmers were offered initial subsidies that probably match the annual return from maize, so it was a no-regret option, enabling them to return to maize if the profits from jatropha turn out to be low. We were informed by a key informant that many farmers had already done this in Chiapas; a case was cited in which 15 of the initial 34 farmers in one village destroyed their plants when they were refused the second subsidy payment, though such high drop-out rates may be unusual.

Regarding social infrastructure, there was no indication that there had been any improvements or investments in community facilities as a result of the jatropha program in any of the communities surveyed.

\section{Impact of jatropha on $\mathrm{CO} 2$ emissions}

One of the underlying motivations of the jatropha program in Mexico is to reduce carbon emissions by providing a green alternative to fossil diesel fuel. The idea that biofuels emit less carbon than fossil fuels has been widely contested, particularly when they are cultivated in areas that were previously forests, since the carbon stocks of the forests are lost when they are cleared (Becker 2009). As noted, in the case of jatropha smallholders in Chiapas and Michoacan, there was little associated loss of forests, but in the commercial farms in Yucatan, secondary forests were being cut on a scale large enough to cause concern. For this reason, we carried out a preliminary carbon balance assessment for one of these farms using the methodology outlined in Methodology: Carbon balance study.

\section{Carbon stocks in the acahual}

The carbon stock in the cleared vegetation depends heavily on the age of the acahual, as shown in Table 3 . When acahual is cleared, not only is the above-ground biomass lost, but there may also be a loss of litter and woody debris (including its carbon stock), and moreover carbon may be lost from the soil, although most of the below-ground biomass in plant roots may be retained and will decompose slowly. Estimating changes in woody debris and litter is very difficult, because, although these layers are likely to be cleared during plantation establishment, some woody material may be retained as mulch. We have therefore excluded this carbon pool from consideration. Regarding soil carbon, this is extraordinarily high in northern Yucatan, even under shifting agriculture; it has been estimated that soil carbon may comprise $80-90 \%$ of the carbon stock in the whole acahual ecosystem (Shang and Tiessen 2003, Eaton and Lawrence 2009). Though it is not possible to estimate the impact of jatropha cultivation on the soil carbon without long-term field studies, the fact that there is no burning of residues involved would imply conservation of this carbon in the short term. Mulching would also partially offset carbon losses.

The company, which is aiming to produce biodiesel for export, is well aware that loss of carbon from the forest may be a variable influencing the marketability of its product, and is using low carbon storage areas in preference to the more dense woodlands for expansion of the jatropha plantation.

\section{Carbon in the biomass of the jatropha plants}

Seventy jatropha plants were measured, of two types: fast growth and moderate growth, the difference between these relating to the soil conditions of particular parts of the site. Wet and dry weights were used to obtain the mass of the plants (above- and below-ground parts). Regression analysis was performed to link the plant dimensions to the weights. Dry and fresh weight of the jatropha plants correlate well $\left(r^{2}=0.888\right)$, 
Table 4. Estimated carbon stock in biomass in jatropha plantation.

\begin{tabular}{lccccccc}
\hline \hline $\begin{array}{l}\text { Growth } \\
\text { scenario }\end{array}$ & $\mathrm{N}$ & $\begin{array}{c}\text { Age } \\
(\text { months })\end{array}$ & $\begin{array}{c}\text { Dry weight } \\
(\mathrm{kg})\end{array}$ & $\begin{array}{c}\text { Carbon per } \\
\text { plant } \\
(\mathrm{kg})\end{array}$ & $\begin{array}{c}\text { Carbon per ha at } \\
1600 \text { plants/ha } \\
\text { tons) }\end{array}$ & $\begin{array}{c}\text { Approx. annual } \\
\text { carbon increment } \\
\text { rate } \\
\text { (tons/ha) }\end{array}$ & $\begin{array}{c}\text { Estimated carbon } \\
\text { stock at 10 years } \\
\text { without pruning } \\
\text { (tons/ha) }\end{array}$ \\
\hline Fast & 30 & 20 & 2.28 & 1.14 & 1.82 & 1 & 10 \\
Moderate & 40 & 20 & 0.83 & 0.42 & 0.67 & 0.4 & 4 \\
\hline
\end{tabular}

meaning fresh weight can be used to estimate dry weight. The average dry weight (whole plant including roots) of individual fast-growing plants at 20 months, the oldest present at the farm at the time of the survey, was $2.285 \mathrm{~kg}$ (equivalent to $1.14 \mathrm{~kg}$ carbon); the weight of moderately growing plants at the same age was $0.813 \mathrm{~kg}(0.42 \mathrm{~kg}$ carbon $)$. For comparison, Reinhardt et al. $(2007,2008)$ estimated the carbon content of jatropha plantations in India to be $2.8 \mathrm{~kg}$ per plant for plants of 3.5 years old (above-ground plus roots).

Assuming a steady growth rate (the correlation between age and weight was strong, $r^{2}=0.80$ ) and a planting density of 1600 per hectare, which is the standard used in the Mexican jatropha program, this would imply carbon stocks of 10 and 4 tons per hectare for fast and moderate-growth, respectively, after 10 years (Table 4), with an average of 7 tons/ha for the whole plantation, assuming these types are equally distributed. Although the jatropha plants may continue to be productive of seeds until they are 20 years old, after which they would be replaced, it is likely that any growth beyond 10 years would be pruned out to ensure that fruits are accessible for harvesting, and indeed pruning to encourage production may be carried out earlier than this. The farm management states that the prunings would be used for mulch, and therefore we have not deducted pruning in the first 10 years in our calculations. The total carbon density over the plantation would depend on the relative mix of fast-growing and slower-growing plants.

\section{Simplified carbon balance analysis}

Although a full life cycle analysis (e.g., using ISO 14040 and 14044) is beyond the scope of this study, two indicative calculations were made: the payback time for replacement of the standing carbon, and the payback time including substitution of fossil diesel by biodiesel.

Based on the rough estimates above, the number of years it would take for carbon levels in the jatropha plants to replace the carbon lost when acahaul is cleared is from 4.5 to 75 years, as shown in Table 5. At an average stock density of 7 tons, the payback time for the plantation would range from 7.8 to 52.5 years depending on the age of the acahual cleared. It is important to note that jatopha will never in practice be able to reach the carbon levels represented by the oldest category of acahual, because its useful life is around 20 years, after which the bushes would be cut and replaced. Thus, clearance of any acahual older than 25 years would lead to net negative carbon stocks, even in the long term.

Table 5. Time needed for jatropha plants to reach the carbon levels of the acahual they replace.

\begin{tabular}{lccc}
\hline \hline $\begin{array}{l}\text { Age of } \\
\text { acahual } \\
\text { (years) }\end{array}$ & $\begin{array}{c}\text { Fast growth } \\
\text { (years) }\end{array}$ & $\begin{array}{c}\text { Moderate } \\
\text { growth } \\
\text { (years) }\end{array}$ & $\begin{array}{c}\text { Average } \\
\text { (years) }\end{array}$ \\
\hline $1-5$ & 4.5 & 11 & 7.8 \\
$5-15$ & 8 & 20 & 14 \\
$>25$ & 30 & 75 & 52.5 \\
(hypothetical & & & \\
case) & & & \\
\hline
\end{tabular}

The balance with regard to substitution of fossil fuel is very dependent on the quantity of biofuel that can be produced per hectare. The company's target is 5 tons of oil per hectare, which is extremely high in comparison with most jatropha plantations; it would imply a seed yield of at least 11 tons per hectare, which is more than double the most optimistic estimates of INIFAB and the Ministry of Agriculture. The farm justifies its expectations on the basis of the fact that they are engaged in selecting and breeding high-yielding varieties, and using pig slurry as manure in the irrigation water. However, Reinhardt et al. (2008) suggest that, under the best conditions, in India 2000 liters/ha (1.7 tons/ha) per year might be produced, which is only about one-third of the company's target. In the calculations below, we have used these as highand low-end estimates but included also an intermediate one that takes into account the relatively high inputs by the Yucatan farm and variations in growth rates of jatropha, which we measured. We have assumed that the stated levels of production would be reached in the sixth year of production with a build up as shown in Table 6 .

Following the detailed carbon cycle analysis of Reinhardt et al. (2007), the total energy inputs (including the cultivation phases, transport, and conversion to oil) in jatropha production in India are equivalent to $15 \mathrm{GJ}$ per hectare per year (about 0.3 tons diesel equivalent, or 0.26 tons carbon). In more intensive cultivation in Thailand (Prueksakorn et al. 2010), 
Table 6. Assumed growth rate in oil production under three scenarios.

\begin{tabular}{|c|c|c|c|c|c|c|}
\hline Tons oil per ha per year & Year 1 & Year 2 & Year 3 & Year 4 & Year 5 & Years $6-10$ \\
\hline Company forecast (5) & 0 & 1 & 2 & 3 & 4 & 5 \\
\hline Intermediate estimate with high-level inputs (3.4) & 0 & 0.68 & 1.36 & 2.04 & 2.72 & 3.4 \\
\hline $\begin{array}{l}\text { Typical farm production level with moderate inputs } \\
\text { (1.7) }\end{array}$ & 0 & 0.34 & 0.68 & 1.02 & 1.36 & 1.7 \\
\hline
\end{tabular}

inputs are quoted as $47 \mathrm{GJ}$ per hectare per year (just over 1 ton diesel equivalent or 0.88 tons carbon). ${ }^{[1]} \mathrm{We}$ assume that, to achieve the very high yields proposed by the jatropha farm we studied, inputs similar to those used in Thailand will be required, and that the two different growth rates observed at the farm would be associated with these two different production scenarios. The intermediate case has been calculated using high inputs because even this level of output would require high-intensity production. A simple carbon balance for these three different production scenarios, by different ages of acahual, would be as shown in Table 7.

It is important to note that many simplifications have been made in these calculations. For example, we have assumed equal inputs every year and linear growth rates of both plant size and oil yield. These rough estimates show that the "carbon footprint" of diesel from jatropha is not negligible and is heavily dependent on the oil yield. Higher-yielding production is much more efficient from a carbon point of view, even though it requires higher carbon inputs. This is largely because, in the short run (10 years), the effect of forest clearance on the carbon balance is greater than that of the inputs. The estimate of 5 tons ( 5880 liters) of oil per hectare or at least 11 tons of seeds per hectare/year is, however, very ambitious and may not be achievable. Moreover, if slow-growing jatropha replaces mature acahual, a positive carbon balance may never be achieved. Moreover, if a complete life cycle analysis were to be made including other greenhouse gas emissions, the carbon balance would certainly move in a more negative direction, because of the high global warming potential of $\mathrm{N}_{2} \mathrm{O}$ resulting from fertilizer use.

\section{CONCLUSIONS}

Most of the "successful" cases of jatropha biofuel production presented in the literature refer to small-scale projects producing for local use. Increased demand in industrialized countries and national policy directives, such as those promulgated in Mexico, are changing the situation dramatically. The program to promote jatropha has, however, only been operating since 2007 , and at this point, there are relatively few cultivators and only a limited area of land is involved. Thus, caution is needed in making predictions of future impacts from these research findings, which only assess early-stage outcomes. Nevertheless, even at this early stage, some social and environmental impacts may be observed. Our main conclusions are that, in these early-adopter cases in Mexico, jatropha does not appear to be a win-win-win wonder plant that is going to provide a profitable alternative to fossil fuels, while at the same time creating large savings in carbon emissions and providing a major new source of income for small farmers.

Regarding its socioeconomic potential for small farmers, which is a key point of debate in the literature (Jongschaap et al. 2007, Achten et al. 2010a), its profitability as a cash crop appears to be marginal at present, and currently farmers are dependent on government subsidies for the establishment costs. Because the subsidies in the first 2 years are more or less equal to the returns farmers now get for their regular crops, it appears that farmers are opting for jatropha as an experiment. It could be argued that they are bearing the cost of trialing an unproven crop (as in the Zambian case study in this collection; German et al. 2011) as they do not yet have a clear view of the input costs, the probable yields, or the selling price of seeds. However, evidently they expect at least to break even in the first 2 years as a result of the subsidy, and planting jatropha does not limit their options in the future, so they have adopted a "wait and see" position. The key to profitability will be the yields attained, and it will be some years before there is any certainty on this. The returns to farmers could possibly be boosted if the by-product (cake) could be sold for cattle fodder or fertilizer, and this may be the most promising avenue regarding further development of the smallholder jatropha sector. On the question of whether jatropha could be considered specially suited as a "poor man's crop" (Openshaw 2000), we found a significant number of poorer farmers engaged in jatropha cultivation, although the majority of jatropha cultivators were drawn from the richer social groups.

Regarding negative social impacts such as land taken over for commercial purposes and consolidation by richer farmers, which have been observed in cases of jatropha production in India, for example (Lahiri 2009, Ariza-Montobbio et al. 2010), our case studies, in keeping with those of Sulle and Nelson (2009), indicated no such impacts yet. The program has, however, brought some increase in labor opportunities for landless people under both modes of production. In contrast to findings of Ariza-Montobbio and Lele (2010), no increased levels of social conflict were signaled in the case study villages. However, the areas under cultivation are as yet small; 
Table 7. Estimated carbon payback time for jatropha.

\begin{tabular}{|c|c|c|c|c|c|c|}
\hline $\begin{array}{l}\text { Scenario (tons oil/ha/ } \\
\text { yr by } 6 \text { th year of } \\
\text { production) }{ }^{\dagger}\end{array}$ & $\begin{array}{l}\text { Oil production over } \\
10 \text { years (tons/ha) }\end{array}$ & $\begin{array}{l}\text { Carbon } \\
\text { Equiv. of oil } \\
\text { produced (tons/ } \\
\text { ha) }\end{array}$ & $\begin{array}{l}\text { Carbon inputs } \\
\text { over } 10 \text { years } \\
\quad \text { (tons } / \mathrm{ha})\end{array}$ & $\begin{array}{l}\text { Net change in } \\
\text { carbon in } \\
\text { biomass (tons, } \\
\text { over } 10 \text { years) }\end{array}$ & $\begin{array}{c}\text { Net annual } \\
\text { balance, averaged } \\
\text { over } 10 \text { years (tons } \\
\mathrm{C} / \mathrm{ha} / \mathrm{yr} \text { ) }\end{array}$ & $\begin{array}{l}\text { Payback period } \\
\text { (years until } \\
\text { positive balance } \\
\text { is reached) }\end{array}$ \\
\hline \multicolumn{7}{|l|}{ Acahual $<5$ years old } \\
\hline 5 & 35 & 30.05 & 8.8 & +5.5 & 2.67 & 2 \\
\hline 3.4 & 23.8 & 20.4 & 8.8 & +2.5 & 1.41 & 3.5 \\
\hline 1.7 & 11.9 & 10.2 & 2.6 & -0.5 & 0.75 & 6 \\
\hline \multicolumn{7}{|l|}{ Acahual 6-10 years old } \\
\hline 5 & 35 & 30.05 & 8.8 & +2.0 & 2.33 & 7 \\
\hline 3.4 & 23.8 & 20.4 & 8.8 & -1.0 & 1.06 & 8 \\
\hline 1.7 & 11.9 & 10.2 & 2.6 & -4.0 & 0.36 & 11 \\
\hline \multicolumn{7}{|l|}{ Acahual $>15$ years old } \\
\hline 5 & 35 & 30.05 & 8.8 & -20.0 & 0.17 & 14 \\
\hline 3.4 & 23.8 & 20.4 & 8.8 & -23 & -1.08 & - \\
\hline 1.7 & 11.9 & 10.2 & 2.6 & -26.0 & -1.84 & - \\
\hline
\end{tabular}

${ }^{\dagger}$ Scenarios with 5 tons oil/ha/year after 6th year assume fast plant growth and high level of inputs. Scenarios with 3.4 tons oil/ha/year assume average growth and high level of inputs. Scenarios with 1.7 tons oil/ha/year assume moderate growth and low inputs. All scenarios assume build up of oil yield in first 5 years as shown in Table 4 .

the social dynamics could change if production increases greatly in the next few years. Moreover, in these areas, jatropha is taking over from maize, and if production were significantly up-scaled, there would be implications for food security as well as for indirect deforestation.

Regarding environmental impacts, the main debate in the literature revolves around the potential of biodiesel from jatropha to mitigate greenhouse gas emissions (Reinhardt et al. 2007, Becker 2009) with the underlying concern that clearing forest areas for jatropha cultivation may prove negative in this regard. Although large-scale deforestation has been observed in some studies of jatropha cultivation (WRM 2008, 2009; Schoneveld et al. 2011), we found that, when grown by smallholders, it has not brought about much direct carbon emission due to deforestation, and moreover that it has not reduced the availability of other forest products and services customarily used by local people. However, on the commercial estates that were previously used for low-intensity grazing, there is extensive secondary woody vegetation (acahual), which is being cleared for jatropha production. This brings into question the overall carbon balance and climate change mitigation role of jatropha under this mode of production. Carbon payback periods of from 2 to 15 years were estimated for most scenarios, although in some cases, particularly where the acahual is mature, a positive carbon balance may never be achieved.

Responses to this article can be read online at: http://www.ecologyandsociety.org/voll6/iss4/art11/ responses/

\section{Acknowledgments:}

This paper has been produced with the financial assistance of the European Union, under a project entitled, "Bioenergy, sustainability and trade-offs: Can we avoid deforestation while promoting bioenergy?" The objective of the project is to contribute to sustainable bioenergy development that benefits local people in developing countries, minimizes negative impacts on local environments and rural livelihoods, and contributes to global climate change mitigation. The project is managed by Center for International Forestry Research and implemented in collaboration with the Council on Scientific and Industrial Research (South Africa), Joanneum Research (Austria), the Universidad Autónoma de México, and the Stockholm Environment Institute. The views expressed herein can in no way be taken to reflect the official opinion of the European Union. Thanks are due to two anonymous reviewers whose insights and comments have strengthened the paper considerably. We would also like to thank Julia McCall, Manuela Prehn, and Melanie Schrenk for their assistance in the fieldwork in Chiapas.

\section{LITERATURE CITED}

Achten, W., W. Maes, R. Aerts, L. Verchot, A. Trabucco, E. Mathijs, V. Singh, and B. Muys. 2010a. Jatropha: from global hype to local opportunity. Journal of Arid Environments 74:164-165. http://dx.doi.org/10.1016/j.jaridenv.2009.08.010 
Achten, W., L. Nielsen, R. Aerts ,A. Lengkeek, E. Kjaer, A. Trabucco, J. Hansen, W. Maes, L. Graudal, F. Akinifesi, and B. Muys. 2010b. Towards domestication of jatropha curcas. Future Science: Biofuels 1(1):91-107.

Ariza-Montobbio, P., and S. Lele. 2010. Jatropha plantations for biodiesel in Tamil Nadu: viability, livelihood trade-offs and latent conflicts. Ecological Ecoonomics 70:189-195. http ://dx.doi.org/10.1016/j.ecolecon.2010.05.011

Ariza-Montobbio, P., S. Lele, G. Kallis, and J. Martinez-Alier. 2010. The political ecology of jatropha plantations in Tamil Nadu. Journal of Peasant Studies 37(4):875-897. http://dx.do i.org/10.1080/03066150.2010.512462

Becker, K. 2009. Biofuels from Jatropha curcas oil: perspectives for tropical regions. OCL 16(4):236-240.

CONAFOR. 2010. Terminos de Referencia, ProArbol. [online] URL: http://www.conafor.gob.mx/portal/index.php/ proarbol/convocatoria-de-reglas-de-operacion-2010/terminosde-referencia

Eaton, J. M., and D. Lawrence. 2009. Loss of carbon sequestration potential after several decades of shifting cultivation in the Southern Yucatan. Forest Ecology and Management 258:949-958. http://dx.doi.org/10.1016/j.foreco .2008 .10 .019

Gerbens-Leens, W., A. Y. Hoekstra, and T. H. van der Meer. 2009. The water footprint of biofuels. Proceedings of the National Academy of Sciences USA 106(25):10219-10223. http://dx.doi.org/10.1039/c1ee01187a

German, L., G. C. Schoneveld, and D. Gumbo. 2011. The local, social, and environmental impacts of smallholder-based biofuel investments in Zambia. Ecology and Society 16(4): 12. http://dx.doi.org/10.5751/ES-04280-160412

Ham, C. 2004. Background report on indigenous fruit commercialisation activities in selected SADC countries. University of Stellenbosch, South Africa.

IICA. 2009. México - Inicia Yucatán cultivo de jatropha para biodiesel 08/282010. [online] URL: http://www.iica.int/Esp/r egiones/sur/argentina/Lists/Noticias/DispForm.aspx?ID=1763

Jongschaap, R. E. E., W. J. Corré, P. S. Bindreban, and W. A. Brandenburg. 2007. Claims and facts on Jatropha curcas L. Report 158 Plant Research International. [online] URL: htt p://www.jatropha.de/news/Claims $\% 20$ and $\% 20$ facts $\% 20$ on $\%$ 20Jatropha\%20curcas\%20L\%5B5\%5D.\%20Wageningen\%20URPlant $\% 20$ Research\%20International-Jongschaap $\% 20$ et $\% 20 \mathrm{al} \%$ 202007.pdf

Kheira, A. A. A., and N. M. M. Atta. 2009. Response of jatropha curcas to water deficits: yield, water use efficiency and oilseed characteristics. Biomass and Bioenergy 33:1343-1350. http://dx.doi.org/10.1016/j.biombioe.2008.05.015
LAERFTE. 2008. Ley de Aprovechamiento de las Fuentes Renovables de Energía y Financiamiento para la Transición Energética. Government of Mexico. [online] URL: http://ww w.diputados.gob.mx/LeyesBiblio/pdf/LAERFTE.pdf

Lahiri, S. 2009. Losing the plot: the threats to community land and the rural poor through the spread of the biofuel jatropha in India. [online] URL: http://www.foeeurope.org/publication s/2010/losing the plot jatropha report Mar10.pdf

Lengkeek, A. 2007. The Jatropha curcas agroforestry strategy of Mali Biocarburant SA. FACT seminar on Jatropha curcas L. agronomy and genetics. Wageningen, the Netherlands.

McCarthy, J. F. 2010. Processes of inclusion and adverse incorporation: oil palm and agrarian change in Sumatra, Indonesia. Journal of Peasant Studies 37(4):821-850. http://d x.doi.org/10.1080/03066150.2010.512460

Milenio. 2010a. Japptam busca biocombustibles. [online] URL: http://www.milenio.com/node/507166

Milenio. 2010b. Plantarán 94 hectáreas de arbustos del género Jatropha. [online] URL: http://impreso.milenio.com/node/8812965

Openshaw, K. 2000. A review of jatropha curcus: an oil plant of unfulfilled promise. Biomass and Bioenergy 19:1-15. http: //dx.doi.org/10.1016/S0961-9534(00)00019-2

Prueksakorn, K., S. Gheewala, P. Malakul, and S. Bonnet. 2010. Energy analaysis of jatropha plantation systems for biodiesel production in Thailand. Energy for Sustainable Development 14:1-5. http://dx.doi.org/10.1016/j.esd.2009.12.002

Raswant, V., N. Hart, and M. Romano. 2008. Biofuel expansion: challenges, risks and opportunities for rural poor people. Prepared for the roundtable in the Thirty-first session of IFAD's Governing Council, Rome, 14 February 2008. [online] URL: http://www.ifad.org/events/gc/31/roundtable/biofuels. pdf

Reinhardt, G., K. Becker, D. R. Chaudhary, J. Chikara, E. von Falkenstein, G. Francis, S. O. Gärtner, M. R. Gandhi, A. Ghosh, P. K. Ghosh, H. P. S. Makkar, J. Münch, J. S. Patolia, M. P. Reddy, N. Rettenmeier, and S. C. Upadhyay. 2008. Basic data for jaropha production and use. IFEU, Heidelberg.

Reinhardt, G., S. Gaertner, N. Rettenemeier, J. Muensch, and E. von Falkstein. 2007. Screening life cycle assessment of jatropha biodiesel. IFEU, Heidelberg.

Robinson, S., and J. Beckerlegge. 2008. Jatropha in Africa: economic potential. [online] URL: http://www.wolfsberg.com/ documents/Jatropha in Africa Economic Potential.pdf

Schoneveld, G. C., L. A. German, and E. Nutakor. 2011. Landbased investments for rural development? A grounded analysis of the local impacts of biofuel feedstock plantations 
in Ghana. Ecology and Society 16(4): 10. http://dx.doi.org/10 $.5751 /$ ES-04424-160410

Shang, C., and H. Tiessen. 2003. Soil organic carbon sequestration and stabilization in karstic soils of Yucatan. Biogeochemistry 62:177-196. http://dx.doi.org/10.1023/A:10 $\underline{21123728639}$

Sulle, E., and F. Nelson. 2009. Biofuels, land access and rural livelihoods in Tanzania. IIED, London, UK.

Tandon, N. 2009. The bio-fuel frenzy: what options for rural women? A case of rural development schizophrenia. Practical Action Publishing, Warwickshire, UK. http://dx.doi.org/10.1 080/13552070802696961

[UN ESA] U.N. Department of Economic and Social Affairs. 2007. Small-scale production and use of liquid biofuels in subSaharan Africa: perspectives for sustainable development. Presented at the 15th session of the Commission on Sustainable Development, New York, 30 April-11 May. [online] URL: http://www.un.org/esa/sustdev/csd/csd15/documents/ csd15 bp2.pdf

Universal, El. 2009. Productores de Veracruz denuncian irregularidades de Conafor. [online] URL: http://www.eluniv ersal.com.mx/notas/607140.html

Wardell, D. A. 1987. Control of termites in nurseries and young plantations in Africa: established practices and alternative courses of action. Commonwealth Forestry Review 66:77-89.

WRM. 2008. Ghana: Norwegian biofuel company destroyed local forest to establish a large jatropha (1) plantation. World Rainforest Movement Bulletin 129. [online] URL: http://www. wrm.org.uy/bulletin/129/Ghana.html

WRM. 2009. Paraguay: acción para proteger a pueblo indígena en aislamiento voluntario no admite demoras. Movimiento Mundial por los Bosques Tropicales Boletín 138. [online] URL: http://www.wrm.org.uy/boletin/138/Paraguay.html

${ }^{[1]}$ Conversion factors used: 1 ton diesel $=42.8 \mathrm{GJ} ; 1$ ton diesel $=1176$ liters; $0.73 \mathrm{~kg} \mathrm{C}$ per liter diesel. 


\section{Appendix 1. Farm budget analysis of jatropha}

The domestic price of fossil fuel diesel in Mexico in December 2009 was 7.09 pesos (US\$0.54) per litre before tax. Although a small environmental subsidy might be considered, it is clear that biofuel competing in this market should not exceed this by a very large margin. Pre-tax prices have varied between US\$1.26 and \$0.65 in Germany and US\$1.14 to \$0.60 in the USA over the period July 2008 to December 2009, so for the export market - taking into account transport costs and a green premium - an average FOB export price of US $\$ 0.70$ (9 pesos) might be considered. Industrial processing of jatropha seed to produce biodiesel costs around 2 pesos per litre including profit margin according to key informants surveyed, which means that the maximum price that can be paid to the farmer ranges between 5 and 7 pesos per litre of biofuel produced. The ratio of seed to biodiesel varies, but is typically 3 kilos to one litre. This puts the maximum viable farm gate price per kilo of seed in the range 1.6 to 2.3 pesos, although probable purchasing prices of 4 pesos and 7 pesos were being quoted by technicians in the jatropha programme in Michoacan and Chiapas respectively.

The main cost to the farmer in jatropha production is harvesting. Based on expert information from producers in Yucatan and Michoacan, it was estimated that a labourer can harvest 10 kilos of fruits per hour, which would yield 49 kilos of seeds per 7 hour day. At the standard labour rate of 70 pesos (\$5.4) per day, the harvest cost per kilogram of seeds is 1.43 pesos (\$0.11). As no economies of scale exist for hand harvesting, this will mean that harvest costs represents between 90 and $62 \%$ of our estimated farm gate price of seed.

The attractiveness of jatropha to the farmer however will depend largely on the opportunity costs, which are estimated in terms of maize and peanut production. Farm gate prices for these crops vary greatly, as do yields; returns are estimated at between 1800 and 4000 pesos (US\$139-310) per hectare in smallholder production in Chiapas and Michoacan, two of the the states included in the survey. At 1.6 pesos per kilo of jatropha seeds, farmers would have to generate yields of 1.15 to 2.5 tonnes/ha to match their previous returns. At 2.3 pesos, yields would have to be 0.75 to 1.75 tonnes/ha. At a (subsidized) price of 4 pesos, farmers would, in theory, match their previous returns at jatropha seed yields of only 0.45 to 1 tonnes/ha. Production rates of 2 tonnes/ha at the end of 5 years could probably be achieved under non-irrigated, low input conditions, and they might rise somewhat after that. However the marginal costs of family labour are very low under current production conditions. If labour costs are factored in using minimum wage rates, it is clear from the gross margin analysis below that jatropha will not be profitable unless yields are above 3 tons/ha and the price is at least 2.3 pesos/kilogram.

\begin{tabular}{|l|l|l|l|l|l|}
\hline \multicolumn{7}{|c|}{ Gross Margin Mature Jatropha Plantations } \\
\hline $\begin{array}{l}\text { Yield } \\
\text { Kg /ha }\end{array}$ & $\begin{array}{l}\text { operating } \\
\text { expenses }\end{array}$ & $\begin{array}{l}\text { crop value } \\
@ 1.6 \text { pesos/kg }\end{array}$ & $\begin{array}{l}\text { profit } \\
@ 1.6 \text { pesos/kg }\end{array}$ & $\begin{array}{l}\text { crop value } \\
@ 2.3 \text { pesos/kg }\end{array}$ & $\begin{array}{l}\text { Profit } \\
\text { @2.3 pesos/kg }\end{array}$ \\
\hline 5000 & 9550 & 8000 & -1550 & 11500 & 1950 \\
\hline 3500 & 7405 & 5600 & -1805 & 8050 & 645 \\
\hline 2000 & 5260 & 3200 & -2060 & 4300 & -660 \\
\hline
\end{tabular}

From this it may appear that jatropha is attractive compared to currently available alternatives, at prices above 2.3 pesos, provided yields are high enough. Below this price, however, revenues will not cover input costs. Jatropha appears to be much more labour intensive than grains and peanuts, and it remains to be seen if farmers will find it worthwhile (i.e. by valuing labour at less than the minimum wage). However, if producers could gain 
other ecomonic benefits through use of the jatropha cake for cattle fodder or fertlizer, or process the oil for their own use, jatropha might become a more viable option, and this may be the key to promoting jatropha more widely in Mexico. Unfortunately, there are no studies available yet to assess how these by-products would affect the overall profitability of Jatropha. 